\title{
Competitive Ability of Soybean Cultivars with Horseweed (Conyza bonariensis) ${ }^{1}$
}

\author{
Habilidade competitiva de cultivares de soja com buva (Conyza bonariensis)
}

\author{
TREZZI, M.M. ${ }^{2}$, BALBINOT JR., A.A. ${ }^{3}$, BENIN, G. ${ }^{2}$, DEBASTIANI, F. ${ }^{4}$, PATEL, F. ${ }^{4}$, and \\ MIOTTO JR., E. ${ }^{4}$
}

\begin{abstract}
The existence of large areas infested with populations of Conyza spp. resistant to glyphosate in Brazil demands appropriate and integrated management strategies. This experiment aimed to identify soybean cultivars with greater competitive ability with horseweed plants and to determine plant characteristics associated with this ability. The experiment was arranged in a randomized complete block design with split plots. Seven soybean cultivars (CD 225 RR, BRS 232, CD 226 RR, NK 7054 RR, BMX Apollo RR, BRS 245 RR and BRS 255 $\mathrm{RR}$ ) were allocated in the plots, and two interference situations (absence and 13.3 plants of Conyza $\mathrm{m}^{-2}$, transplanted seven days before soybean planting) in the subplots. The average yield loss due to competition with horseweed was 25\%. Cultivar CD 226 RR showed no significant grain yield loss due to competition, compared to the control without infestation, but showed the lowest average grain yield. The BRS 232 genotype showed loss of grain yield of only $14 \%$, and presented positive plant height and leaf mass at 20 DAE, as well as dry matter of stems+branches in all evaluations, features related to its higher performance and greater ability to withstand competition with horseweed plants.
\end{abstract}

Keywords: Conyza spp., interference, competition, grain yield.

\begin{abstract}
RESUMO - A existência de extensas áreas infestadas com populações de buva (Conyza spp.) resistentes ao glyphosate no Brasil demanda estratégias de manejo adequadas e integradas. Os objetivos deste experimento foram identificar cultivares de soja com maior habilidade competitiva com plantas de buva e determinar características de plantas de soja associadas a essa habilidade. $O$ delineamento utilizado foi em blocos completos ao acaso, com parcelas subdivididas. Nas parcelas foram alocados sete cultivares de soja (CD 225 RR, BRS 232, CD 226 RR, NK 7054 RR, BMX Apollo $R R, B R S 245$ RR e BRS 255 RR) e, nas subparcelas, duas situações de interferência (ausência e 13,3 plantas de buva $m^{-2}$, transplantadas sete dias antes da semeadura da soja). A perda média de rendimento de grãos por competição com buva foi de 25\%. O cultivar CD 226 RR não apresentou perda significativa de rendimento em relação à testemunha sem infestação, porém mostrou o menor rendimento médio. O cultivar BRS 232 apresentou perda percentual de rendimento de apenas 14\%. Este cultivar destacou-se positivamente quanto à estatura de planta e matéria de folhas secas aos 20 $D A E$ e matéria seca de caules+ramificações em todas as avaliações, características relacionadas ao seu maior desempen ho produtivo e sua maior habilidade em suportar a competição com buva.
\end{abstract}

Palavras-chave: Conyza spp., interferência, competição, rendimento de grãos.

Recebido para publicação em 8.7.2012 e aprovado em 11.12.2012.

2 Professor, Dr., Curso de Agronomia, Universidade Tecnológica Federal do Paraná - UTFPR, Campus Pato Branco, Via do Conhecimento, Km 01, Caixa Postal 571, 85503-390 Pato Branco-PR; ${ }^{3}$ Pesquisador, Dr., EMBRAPA Soja, Londrina-PR; ${ }^{4}$ EngenheiroAgrônomo, UTFPR.

Planta Daninha, Viçosa-MG, v. 31, n. 3, p. 543-550, 2013 


\section{INTRODUCTION}

The weed management based on the use of herbicides has provided the development of production systems relatively simple, allowing the increase of cultivated area and productivity. Moreover, the strong dependence of chemical control has caused undesirable effects such as changing the weed flora, emergence of resistant (R) weeds and problems of environmental contamination (Buhler, 2002).

The selection of species with tolerance to the herbicide glyphosate is a process that occurs since the commercial release of the herbicide, in the 1970 s, but which has intensified in plantations across Brazil in recent years. Currently, besides the problem with tolerant species, it is estimated that there are millions of acres infested with biotypes of weeds resistant to glyphosate, primarily in the states of Rio Grande do Sul, Santa Catarina, Paraná and São Paulo. In three species of horseweed, (Conyza canadensis, Conyza bonariensis and $C$. sumatrensis) the resistance to glyphosate was detected (Montezuma et al., 2006; Vargas et al., 2007; Heap, 2012).

Currently, populations of horseweed resistant to glyphosate are widespread in several regions of Brazil, focusing on the South. In Paraná, the first cases were found in the west and north, and they are currently widespread in southwestern Paraná. The occurrence of large populations of horseweed $\mathrm{R}$ in Paraná is associated with the intensive use of glyphosate in crops and also the cropping systems that provide low vegetation cover during the winter period.

The occurrence of $\mathrm{R}$ biotypes indicates the need for adoption of integrated weed management in various tactics that are integrated, so that the focus of the control is not only the chemical.

Studies on crop competitiveness with weeds allow the development of strategies for their inclusion in integrated management, giving an advantage to the farmer with regard to weed management (Lemerle et al., 2001; Balbinot Jr. et al., 2003). Competitive ability is understood as the capacity of a plant or crop to take advantage in the competition with their neighbors. The competitive ability is characterized by the ability of a plant to suppress the growth of other, or to maintain its growth relatively unchanged in the presence of competitors, thus avoiding being suppressed (Landa \& Goldberg, 1991).

Overall, the soybean cultivars released in Brazil have differential morphological characteristics. Among the characteristics of soybean plants with superior competitive ability are: high dry matter accumulation in the aerial part (Bianchi et al., 2006; Place et al., 2011), greater ground coverage in early stages (Jannink et al., 2000; Bianchi et al., 2006; Place et al., 2011), higher plant height (Jannink et al., 2000; Lamego et al., 2004; Place et al., 2011) and early flowering (Jannink et al., 2000). However, it is necessary to reconcile high competitiveness with high grain yield. There is no data in the literature on the competitiveness of modern soybean cultivars with specific reference to horseweed as competitor species.

This study aimed to identify soybean cultivars with greater competitive ability with horseweed plants and determine characteristics of soybean associated with this skill.

\section{MATERIAL AND METHODS}

The study was conducted in two stages. The first, preparatory, was conducted in the greenhouse and the second, in the field. The field area is located at latitude $26^{\circ}$ south, longitude $52^{\circ}$ west, altitude 700 meters; has $\mathrm{Cfb}$ climate and clay soil, identified as Dystroferric Red Latosol (Oxisol) (Bhering \& Santos, 2008).

In the greenhouse, we carried out the process of obtaining horseweed (Conyza bonariensis), seedlings, using PVC trays with cells filled with organic mineral substrate, which were sowed. Conyza bonariensis seeds were purchased from the company Agro Cosmos Ltda., and were susceptible to the herbicide glyphosate. After sowing, the daily watering of seedlings was held until the time of transplanting them to the field, about a month after sowing, when they had approximately three expanded leaves. 
For the field phase, the experimental design was composed of randomized complete blocks in split plots with three replications, in which, in the main plots were arranged seven soybean cultivars (Table 1) and, in the subplots, two interference conditions (without and with 13.3 horseweed plants $\mathrm{m}^{-2}$ ). In each block, only a plot was added with horseweed at the same density and lack of interference with soybeans. Each experimental unit was composed of five soybean lines spaced $0.45 \mathrm{~m}$, with a total area of $9 \mathrm{~m}^{2}(5 \times 1,80 \mathrm{~m})$.

About 30 days before the deployment of the experiment, the area was prepared with tillage followed by leveling. We proceeded to desiccate the area with glyphosate about 20 days before transplanting of horseweed, which was held seven days before planting soybeans. The soybean cultivars were planted manually, to obtain 330.000 plants ha-1. We used 0-64$64 \mathrm{~kg} \mathrm{ha}{ }^{-1}$ of $\mathrm{N}-\mathrm{P}_{2} \mathrm{O}_{5}-\mathrm{K}_{2} \mathrm{O}$ of the fertilizer formulated $0-20-20$ in the seeding row based on the need determined by soil analysis.

The treatments to control pests and diseases were made so that they would not undermine the development of the culture (Embrapa, 2009).

During the experiment, we proceeded to irrigation of the experimental area when necessary, during the first 60 days of development of the species, in order to ensure the establishment of horseweed and soybean seedlings.

The determinations performed in soybean were: 1) plant height at 20, 35 and 65 days after emergence (DAE) and at harvest, obtained by measuring with a ruler the distance between

Table 1 - Relationship of soybean cultivars used, detailing their growth habits and maturity groups

\begin{tabular}{|l|l|c|}
\hline \multicolumn{1}{|c|}{ Cultivar } & \multicolumn{1}{c|}{ Growth Habit } & Maturity Group \\
\hline CD 225 RR & Undetermined & 5.8 \\
\hline BRS 232 & Determined & 6.9 \\
\hline CD 226 RR & Determined & 6.6 \\
\hline NK 7054RR & Undetermined & 5.3 \\
\hline BMX Apollo RR & Undetermined & 5.5 \\
\hline BRS 245 RR & Determined & 7.5 \\
\hline BRS 255 RR & Determined & 6.6 \\
\hline
\end{tabular}

the base of the plant near the ground and the height of inflection of the highest leaf; 2) dry matter from the aerial part (MSPA) at 20, 35 and $65 \mathrm{DAE}$, by drying the plants in an oven until constant matter, which was split in dry weight of stems+branches (SBDM) and dry matter of leaves (LDM); 3) chlorophyll content in leaves at 20, 35 and 65 estimated DAE using the equipment ClorofiLOG (Falker Automação Agrícola Ltda.); 4) number of branches per plant at $65 \mathrm{DAE}$, by direct counting of the number of branches inserted into the main stem of the soybean plant; 5) leaf area index (LAI) at $65 \mathrm{DAE}$, determined by the ratio of leaf area of plants, obtained by leaf area integrator LI-COR, model 3100, and ground area occupied by them; and 6) yield of soybeans.

Measurements of leaf area and dry weight were made on five soybean plants, taken from the line intended for destructive sample. The height, number of branches and chlorophyll content were determined in five random plants in each subplot, and the chlorophyll content was determined in the central leaflet of the penultimate leaf. Grain yield was determined in two central rows of each subplot, ignoring $0.5 \mathrm{~m}$ from the ends of each line. For horseweed, the dry matter of the aerial part (HDM) was evaluated at 35 and $65 \mathrm{DAE}$ and in the harvest of soybean.

The data collected from the experiments were subjected to analysis of variance. When significant for $\mathrm{F}$ test $(\mathrm{P} \leq 0.05$ for main effects and $\mathrm{P} \leq 0.15$ for interactions), we performed Tukey's test at $5 \%$ error probability.

\section{RESULTS AND DISCUSSION}

In the evaluation performed early, at 20 DAE, the BRS 232 cultivar showed the highest plant height, both with interference of horseweed and without, demonstrating rapid initial growth in height (Table 2). Cultivars CD 225 RR and BMX Apollo RR constituted the group with lower height values, in the condition of no interference, and BMX Apollo RR, CD $225 \mathrm{RR}$ and BR $255 \mathrm{RR}$, the lowest values in the condition of interference with horseweed. Cultivars responded differently to the interference condition. At $20 \mathrm{DAE}$, the BRS 232 cultivar was unique in that there was a reduction in the height at interference 
Table 2 - Plant height in seven soybean cultivars subjected or not to interference with horseweed in four different times. Pato BrancoPR, 2010

\begin{tabular}{|c|c|c|c|c|c|}
\hline \multirow{3}{*}{ Cultivar } & \multicolumn{5}{|c|}{ Plant height $(\mathrm{cm})$} \\
\hline & \multicolumn{2}{|c|}{$20 \mathrm{DAE}$} & \multirow{2}{*}{$\frac{35 \text { DAE }}{\text { Mean }}$} & \multirow{2}{*}{$\frac{65 \text { DAE }}{\text { Mean }}$} & \multirow{2}{*}{$\frac{119 \mathrm{DAE}}{\text { Mean }}$} \\
\hline & $\mathrm{SI}^{\frac{1 /}{}}$ & CI & & & \\
\hline CD225 RR & $16.3 \mathrm{Da}^{2 /}$ & $17.9 \mathrm{BCa}$ & $50.4 \mathrm{~B}$ & $122.2 \mathrm{~A}$ & $113.4 \mathrm{~A}$ \\
\hline BRS 232 & 28.8 Aa & $26.7 \mathrm{Ab}$ & $60.8 \mathrm{~A}$ & $119.2 \mathrm{AB}$ & $89.2 \mathrm{BC}$ \\
\hline CD226 RR & $22.1 \mathrm{Ba}$ & $21.9 \mathrm{Ba}$ & $51.2 \mathrm{~B}$ & $123.8 \mathrm{~A}$ & $97.5 \mathrm{AB}$ \\
\hline NK 7054 RR & $20.3 \mathrm{BCb}$ & $22.8 \mathrm{Ba}$ & $49.4 \quad \mathrm{~B}$ & $102.5 \mathrm{C}$ & $82.9 \mathrm{C}$ \\
\hline BMX Apollo RR & $17.9 \mathrm{CDa}$ & $18.7 \mathrm{CDa}$ & $42.5 \mathrm{C}$ & $87.4 \mathrm{D}$ & $61.2 \mathrm{D}$ \\
\hline BRS 245 RR & $21.3 \mathrm{Ba}$ & $22.3 \mathrm{Ba}$ & $48.2 \mathrm{~B}$ & $104.0 \mathrm{C}$ & $87.7 \quad \mathrm{BC}$ \\
\hline BRS 255 RR & $22.3 \mathrm{Ba}$ & $21.0 \mathrm{BCa}$ & $52.7 \mathrm{~B}$ & $109.8 \mathrm{BC}$ & $80.7 \mathrm{C}$ \\
\hline $\mathrm{CV}(\%)$ & & & 4.9 & 5.3 & 7.2 \\
\hline
\end{tabular}

${ }^{1 /} \mathrm{SI}=$ without interference with horseweed; $\mathrm{CI}=$ with interference with horseweed. ${ }^{2 /}$ Means followed by the same letters, lowercase in rows and uppercase in columns, do not differ amongst themselves $(\mathrm{P} \leq 0.05)$ by Tukey's test. DAE $=$ days after emergence.

condition, compared to the condition without interference. The cultivar NK $7054 \mathrm{RR}$ had increased height under interference. The other cultivars were not affected by interference with horseweed.

The literature attributes the plastic response to increased plant height under interference, as occurred in NK 7054 RR, the likely etiolation due to the detection of lowquality solar radiation. This phenomenon has received the designation of "initialism" (Vidal $\&$ Merotto Jr., 2010). The response presented by BRS 232 with respect to height growth indicates greater sensitivity to interference from the early stages of development.

At $35 \mathrm{DAE}$, the cultivar BRS 232 and, at $65 \mathrm{DAE}$, the cultivar CD $226 \mathrm{RR}$ had the highest plant height, but this cultivar did not differ from CD $225 \mathrm{RR}$ at $65 \mathrm{DAE}$ (Table 1). At $119 \mathrm{DAE}$, in the assessment of height in the pre-harvest of soybean plants, cultivar CD 225 RR showed the highest stature, followed by CD $226 \mathrm{RR}$. The cultivar BMX Apollo RR showed the lowest plant height among cultivars. Plant height is an important feature of the competitive ability of soybean plants with weeds (Jannink et al., 2000; Lamego et al., 2004; Place et al., 2011) because it affects the ability of the culture to intercept solar radiation.

The LAI reduction caused by interference with horseweed plants, in the average of cultivars was $13 \%$ (Table 3 ). Among all cultivars evaluated, only CD 225 RR and BRS 245 RR had significant reduction in the LAI, due to the interference of horseweed plants (Table 3). In the absence of interference, the BRS 255 RR had higher LAI than NK 7054 RR and BMX Apollo RR. In the presence of interference, the BRS 255 cultivar also reached the highest value of LAI, not differing from CD $226 \mathrm{RR}$, NK 7054 RR and BRS 245 RR.

In the mean of cultivars, the number of branches was reduced by $15.2 \%$ compared to control, but this difference was not statistically significant, probably due to the high coefficient of variation for this variable (Table 3). In an experiment that evaluated the competition of soybean cultivars with a weeds simulator (both with about 35 plants $\mathrm{m}^{-2}$ ), Bianchi et al. (2006) found a reduction of $17 \%$ in the number of branches in the interference condition. In a study of competition of soybean with an infestation of dicotyledonous weed species, this reduction was $42 \%$ in the number of branches and $44 \%$ of the length of the branches, compared with controls without competition.

At $20 \mathrm{DAE}$, in the condition without interference, BRS 232 was the one that had the greatest leaf dry matter (LDM) (Table 4) but did not differ significantly from cultivars CD 225 RR, NK 7054 RR, BMX Apollo RR and BRS 255 RR. Cultivars CD 226 RR and BRS 245 RR showed the lowest values of LDM. LDM of soybean cultivars was 37 and $9.4 \%$ lower at 35 and $65 \mathrm{DAE}$, respectively, in the condition of interference with horseweed plants $\mathrm{m}^{-2}$ (Table 4). 
Table 3 - Leaf area index and number of branches per plant at 65 days after emergence in seven soybean cultivars subjected or not to interference with horseweed. Pato Branco-PR, 2010

\begin{tabular}{|l|c|c|c|}
\hline \multirow{2}{*}{ Cultivar } & \multicolumn{2}{|c|}{ Leaf area index $\left(\mathrm{m}^{2} \mathrm{~m}^{-2}\right)$} & Branches per plant $\left(\mathrm{n}^{\mathrm{o}}\right)$ \\
\cline { 2 - 4 } & $0.784 \mathrm{SI}^{1 /}$ & $0.732 \mathrm{aA}$ & Mean \\
\hline BRS 255 RR & $0.708 \mathrm{aAB}$ & $0.621 \mathrm{aAB}$ & $0.70 \mathrm{C}$ \\
\hline CD226 RR & $0.740 \mathrm{aAB}$ & $0.591 \mathrm{bAB}$ & $1.98 \mathrm{BC}$ \\
\hline BRS 245 RR & $0.719 \mathrm{aAB}$ & $0.520 \mathrm{bB}$ & $3.05 \mathrm{AB}$ \\
\hline CD225 RR & $0.646 \mathrm{aABC}$ & $0.533 \mathrm{aB}$ & $2.08 \mathrm{BC}$ \\
\hline BRS 232 & $0.575 \mathrm{aBC}$ & $0.596 \mathrm{aAB}$ & $2.39 \mathrm{AB}$ \\
\hline NK 7054 RR & $0.498 \mathrm{aC}$ & $0.472 \mathrm{aB}$ & $3.53 \mathrm{~A}$ \\
\hline BMX Apollo RR & & 10.9 & 29 \\
\hline CV $(\%)$ & & & \\
\hline
\end{tabular}

${ }^{1 /} \mathrm{SI}=$ without interference with horseweed; $\mathrm{CI}=$ with interference with horseweed. ${ }^{2 /}$ Means followed by the same letters, lowercase in rows and uppercase in columns, do not differ amongst themselves $(\mathrm{P} \leq 0.05)$ by Tukey's test

Table 4 - Dry matter of leaves of seven soybean cultivars subjected or not to interference with horseweed, in three different times. Pato Branco-PR, 2010

\begin{tabular}{|c|c|c|c|c|c|c|}
\hline \multirow{3}{*}{ Cultivar } & \multicolumn{6}{|c|}{ Dry matter of leaves $\left(\mathrm{g} \mathrm{m}^{-2}\right)$} \\
\hline & \multicolumn{2}{|c|}{$20 \mathrm{DAE}$} & \multicolumn{2}{|c|}{$35 \mathrm{DAE}$} & \multicolumn{2}{|c|}{$65 \mathrm{DAE}$} \\
\hline & $\mathrm{SI}^{1 /}$ & CI & \multirow{2}{*}{$\frac{\text { SI }}{112.26^{\mathrm{ns}}}$} & \multirow{2}{*}{$\frac{\text { CI }}{53.99}$} & \multirow{2}{*}{$\frac{\text { SI }}{468.38^{\mathrm{ns}}}$} & \multirow{2}{*}{$\frac{C I}{303.51}$} \\
\hline CD225 RR & $16.28 \mathrm{Aba}^{2 /}$ & $18.26 \mathrm{Aa}$ & & & & \\
\hline BRS 232 & $23.10 \mathrm{Aa}$ & $19.80 \mathrm{Aa}$ & 133.62 & 92.77 & 345.73 & 289.76 \\
\hline CD $226 \mathrm{RR}$ & $13.86 \mathrm{Bb}$ & $21.34 \mathrm{Aa}$ & 118.03 & 96.16 & 389.96 & 322.56 \\
\hline NK 7054 RR & $16.50 \mathrm{ABa}$ & $20.46 \mathrm{Aa}$ & 100.49 & 64.17 & 293.70 & 347.95 \\
\hline BMX Apollo RR & $16.28 \mathrm{ABa}$ & $17.60 \mathrm{Aa}$ & 89.76 & 71.02 & 310.53 & 310.84 \\
\hline BRS 245 RR & $14.52 \mathrm{Ba}$ & $15.84 \mathrm{Aa}$ & 121.22 & 91.37 & 390.76 & 298.47 \\
\hline BRS 255 RR & $17.38 \mathrm{ABa}$ & $13.64 \mathrm{Aa}$ & 139.43 & 71.39 & 410.70 & 388.96 \\
\hline Mean & 16.85 & 18.13 & $116.40 \mathrm{a}$ & $77.26 \mathrm{~b}$ & $356.90 \mathrm{a}$ & $323.15 \mathrm{~b}$ \\
\hline $\mathrm{CV}(\%)$ & \multicolumn{2}{|c|}{17.2} & \multicolumn{2}{|c|}{20.1} & \multicolumn{2}{|c|}{19.6} \\
\hline
\end{tabular}

${ }^{1 /} \mathrm{SI}=$ without interference with horseweed; $\mathrm{CI}=$ with interference with horseweed. ${ }^{2 /}$ Means followed by the same letters, lowercase in rows and uppercase in columns, do not differ amongst themselves $(\mathrm{P} \leq 0.05)$ by Tukey's test. ${ }^{\text {ns }}$ Not significant by $\mathrm{F}$ test $(\mathrm{P}>0.05)$.

The interference of horseweed conditioned a $34 \%$ reduction in dry matter of stems+ branches (SBDM) at $35 \mathrm{DAE}$ and $21 \%$ at 119 DAE (Table 5). In virtually all assessments, in average condition with and without interference, the BRS-232 cultivar can be highlighted, with the highest value of SBDM. In the first assessment, at $20 \mathrm{DAE}$, the group of cultivars with higher values were larger, and BRS 232 showed values similar to those of cultivars CD 225 RR, CD 226 RR, NK 7054 RR and BMX Apollo RR. Overall, the cultivars BRS 255 RR and BRS 245 RR were always in the group with the lowest mean SBDM.
At $65 \mathrm{DAE}$, it was possible to analyze the interaction between the factors.

The presence of horseweed plants resulted in significant reduction in SBDM of cultivars CD 225 RR and CD 226 RR. Only the cultivar NK 7054 RR had this variable increased when in competition with horseweed (Table 5). Plastic response of NK 7054 RR to the presence of horseweed plants had been found in the evaluation of stature, but in the earliest stage, 20 DAE.

At 35 DAE, there was no effect of treatment on the chlorophyll content (Table 6). Evaluation 
Table 5 - Dry matter of stems+branches of seven soybean cultivars subjected or not to interference with horseweed, in four different times. Pato Branco-PR, 2010

\begin{tabular}{|c|c|c|c|c|c|c|c|c|c|}
\hline \multirow{3}{*}{ Cultivar } & \multicolumn{9}{|c|}{ Dry matter of stems+branches $\left(\mathrm{g} \mathrm{m}^{-2}\right)$} \\
\hline & \multirow{2}{*}{$\begin{array}{c}20 \text { DAE } \\
\text { Mean }\end{array}$} & \multicolumn{3}{|c|}{$35 \mathrm{DAE}$} & \multicolumn{2}{|c|}{$65 \mathrm{DAE}$} & \multicolumn{3}{|c|}{$119 \mathrm{DAE}$} \\
\hline & & $\mathrm{SI}^{1 /}$ & $\mathrm{CI}$ & Mean & SI & $\mathrm{CI}$ & SI & $\mathrm{CI}$ & Mean \\
\hline CD225* & $7,3 \quad \mathrm{AB}^{2 !}$ & $40.59^{\mathrm{ns}}$ & 24.6 & $32.60 \mathrm{BC}$ & $323.2 \mathrm{aAB}$ & $213.3 \mathrm{bB}$ & 227.8 & 163.1 & $195.46 \mathrm{AB}$ \\
\hline BRS 232 & $10,4 \mathrm{~A}$ & 56.41 & 41.8 & $49.10 \mathrm{~A}$ & $301.3 \mathrm{aABC}$ & $232.1 \mathrm{aAB}$ & 259.1 & 208.2 & $233.64 \mathrm{~A}$ \\
\hline CD226* & $6,8 \mathrm{AB}$ & 43.49 & 29.6 & $36.56 \mathrm{~B}$ & $354.6 \mathrm{aA}$ & $243.0 \mathrm{bAB}$ & 236.2 & 215.5 & $225.82 \mathrm{~A}$ \\
\hline NK 7054* & $8,3 \mathrm{AB}$ & 28.34 & 19.3 & $23.80 \mathrm{C}$ & $212.6 \mathrm{bC}$ & $315.3 \mathrm{aA}$ & 159.1 & 128.9 & $144.01 \mathrm{CD}$ \\
\hline BMX Apollo RR* & $6,9 \mathrm{AB}$ & 28.89 & 22.2 & $25.52 \mathrm{BC}$ & $222.0 \mathrm{aC}$ & $215.7 \mathrm{aAB}$ & 132.7 & 100.8 & 116.77 D \\
\hline BRS 245* & $5,8 \mathrm{~B}$ & 37.84 & 23.5 & $30.68 \mathrm{BC}$ & $242.9 \mathrm{aBC}$ & $201.7 \mathrm{aB}$ & 173.8 & 152.6 & $163.20 \mathrm{BC}$ \\
\hline BRS 255* & $5,3 \mathrm{~B}$ & 46.64 & 25.3 & $35.96 \mathrm{~B}$ & $248.6 \mathrm{aBC}$ & $252.5 \mathrm{aAB}$ & 183.0 & 115.4 & $149.18 \mathrm{CD}$ \\
\hline Mean & 7,25 & $40.3 \mathrm{a}$ & $26.6 \mathrm{~b}$ & & 272.2 & 239.1 & $195.9 \mathrm{a}$ & $154.9 \mathrm{~b}$ & \\
\hline $\mathrm{CV}(\%)$ & 29.7 & \multicolumn{3}{|c|}{18.0} & \multicolumn{2}{|c|}{25.3} & \multicolumn{3}{|c|}{12.4} \\
\hline
\end{tabular}

${ }^{1 /} \mathrm{SI}=$ without interference with horseweed; $\mathrm{CI}=$ with interference with horseweed. ${ }^{2 /}$ Means followed by the same letters, lowercase in rows and uppercase in columns, do not differ amongst themselves $(\mathrm{P} \leq 0.05)$ by Tukey's test. ${ }^{\text {ns }}$ Not significant by F test $(\mathrm{P}>0.05)$.

Table 6 - Chlorophyll content of seven soybean cultivars subjected or not to interference with horseweed, in two different times. Pato Branco-PR, 2010

\begin{tabular}{|l|c|c|c|}
\hline \multirow{2}{*}{ Cultivar } & \multicolumn{3}{|c|}{ Chlorophyll content (\%) } \\
\cline { 2 - 4 } & \multicolumn{2}{|c|}{$35 \mathrm{DAE}$} & $65 \mathrm{DAE}$ \\
\cline { 2 - 4 } & $\mathrm{SI}^{1 /}$ & $\mathrm{CI}$ & Mean \\
\hline BRS 232 & $40.50^{\mathrm{ns}}$ & 39.07 & $42.89 \mathrm{~A}^{\text {2! }}$ \\
\hline CD226 RR & 56.65 & 34.07 & $42.10 \mathrm{AB}$ \\
\hline BRS 255 RR & 38.98 & 36.61 & $39.79 \mathrm{ABC}$ \\
\hline NK 7054 RR & 35.07 & 33.31 & $39.40 \mathrm{BC}$ \\
\hline CD225 RR & 34.65 & 34.33 & $39.37 \mathrm{BC}$ \\
\hline BMX Apollo RR & 36.99 & 35.33 & $39.02 \mathrm{BC}$ \\
\hline BRS 245 RR & 37.57 & 39.21 & $38.55 \mathrm{C}$ \\
\hline Mean & 40.06 & 35.99 & 40.16 \\
\hline CV (\%) & \multicolumn{2}{|c|}{28.7} & 4.7 \\
\hline
\end{tabular}

${ }_{1 /} \mathrm{SI}=$ without interference with horseweed; $\mathrm{CI}=$ with interference with horseweed. "2/ Means followed by the same letters, do not differ amongst themselves $(\mathrm{P} \leq 0.05)$ by Tukey's test. ${ }^{\text {ns }}$ Not significant by $\mathrm{F}$ test $(\mathrm{P}>0.05)$

of chlorophyll at $65 \mathrm{DAE}$ only found differences between soybean cultivars, highlighting the BRS 232 with the highest content, followed by CD 226 RR and BRS 255 RR, while the cultivar BRS 245 RR showed the lowest value. The chlorophyll content in the leaves may be associated with higher photosynthetic rate and hence the higher dry matter accumulation in the plant. However, the fact that no differences were detected between the situation with and without competition, at 35 and $65 \mathrm{DAE}$, indicates, at first, that this parameter is not a sensitive indicator of interference with horseweed plants, while other variables such as $\operatorname{LDM}(20,35,65)$ and SBDM (35 and $65 \mathrm{DAE}$ ) were more sensitive indicators of interference with horseweed plants.

Grain yields in the treatments without horseweed ranged between 1.730 and $2.808 \mathrm{~kg} \mathrm{ha}^{-1}$, while the grain yield of the treatments with horseweed ranged between 1.544 and $2.382 \mathrm{~kg} \mathrm{ha}^{-1}$ (Figure 1). Berefore, in the mean among cultivars, the loss due to interference ( 13.3 plants $\mathrm{m}^{-2}$ ) was of $25 \%$.

In the absence of interference with horseweed, the BRS 232 reached the highest grain yield. Cultivars CD 226 RR, BRS 245 RR and BRS $255 \mathrm{RR}$ had the lowest productivity (Figure 1). The cultivars NK 7054 RR, BMX Apollo RR and CD 225 RR showed intermediate grain yields, not differing from BRS 232 nor from the group with the lowest grain yield. In the interference condition with horseweed, cultivars BRS 232, NK 7054 RR and BMX Apollo RR stood out by their superior grain yield, while CD $226 \mathrm{RR}$ had the lowest grain yield (Figure 1). CD 225 RR and BRS 255 RR achieved intermediate grain yields.

Comparing the differences in grain yield within each cultivar, between the scenarios with and without interference, it is observed that they all showed a reduction in income due to interference with the horseweed plants, with the exception of CD 226 RR. However, 


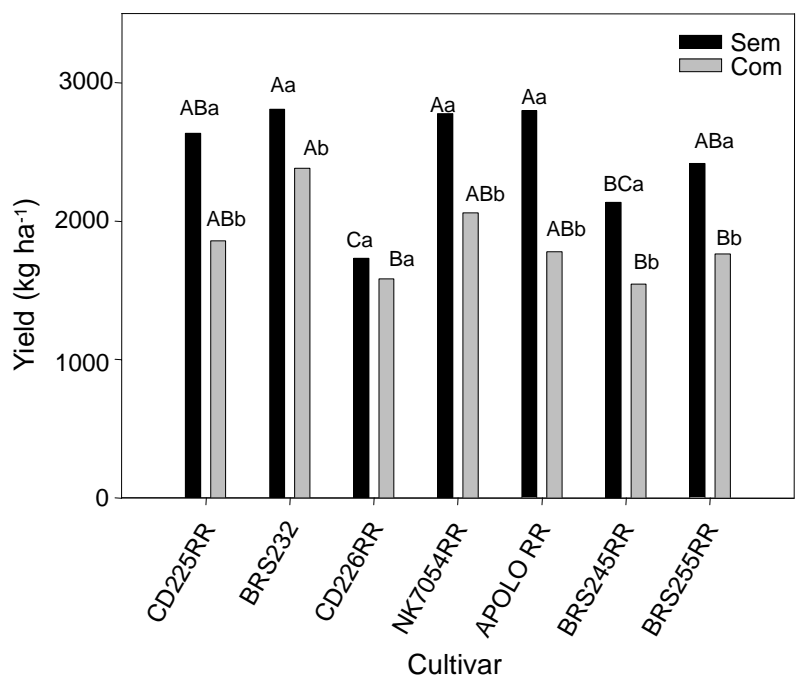

Figure 1 - Grain yield of seven soybean cultivars subjected or not to interference with horseweed. Pato Branco-PR, 2010. Same lowercase letter indicates no significant difference between the conditions with and without horseweed, within each cultivar; same capital letter indicates no significant difference among cultivars within the condition with and without horseweed, both by Tukey's test at $5 \%$ probability.

CD 226 RR had the lowest yield in the absence of interference. The cultivar BMX Apollo RR suffered the greatest loss percentage yield $(35 \%)$ in the scenario with interference, compared to the absence of interference, demonstrating poor competitive ability with horseweed. The cultivars CD 225 RR, BRS 255 RR, BRS 245 RR and NK 7054 RR suffered intermediate reductions and had income losses of 30, 28, 27 and 25\%, respectively. The cultivar BRS 232 showed yield loss of only $14 \%$. It is important that the high competitive ability of a cultivar is accompanied by a high yield potential, to enable its use by farmers (Balbinot Jr. et al., 2003).

Often, the selection of more productive cultivars in the absence of competition, also results in more productive cultivars under competition (Bianchi et al., 2010). In this regard, it is noteworthy that the cultivar BMX Apollo RR is one of those who have been showing greater productive potential in the southwest region of Paraná. For this cultivar, low ability to maintain high yield potential of soybeans when in competition may be related to loss of adaptive traits that allow it to withstand the competitive process during the selection process for higher grain yield, such as the reduced height, low LAI and low LDM.

The treatments did not affect the horseweed dry matter (HDM) at $35 \mathrm{DAE}$, probably due to the short period of coexistence with the soybean crop. At $65 \mathrm{DAE}$, the results were significant only for the cultivar factor (Table 7). The check, in the absence of soybean plants, showed the highest dry matter - expected result, due to the absence of interspecific competition. The highlights, due to the ability to reduce the HDM, are cultivars CD $226 \mathrm{RR}$ and BRS $245 \mathrm{RR}$. The other cultivars (CD 225 RR, BRS 232, NK 7054 RR, BMX Apollo RR and BRS 255 RR) resulted in intermediate values of HDM between the control without soybean plants and cultivars CD $226 \mathrm{RR}$ and BRS $245 \mathrm{RR}$. These data indicate a small predominance of cultivars $C D$ $226 \mathrm{RR}$ and BRS $245 \mathrm{RR}$ compared to other suppressive ability in the development of the shoots of horseweed. However, both cultivars were mentioned in a lower level of grain yield.

Lack of correlation between tolerance to competition and the suppressive capacity of weed development by soybean cultivars was detected in an experiment conducted by Vollmann et al. (2010). For these authors, the loss of grain yield of soybean cultivars was lower in the early maturity group, compared

Table 7 - Dry matter of the aerial part of horseweed submitted to competition with seven soybean cultivars, in three different times. Pato Branco-PR, 2010

\begin{tabular}{|l|c|l|l|}
\hline \multirow{2}{*}{ Treatment } & \multicolumn{3}{|c|}{ Dry matter of horseweed $\left(\mathrm{g} \mathrm{m}^{-2}\right)$} \\
\cline { 2 - 4 } & $35 \mathrm{DAE}^{1 /}$ & $65 \mathrm{DAE}$ & $119 \mathrm{DAE}$ \\
\hline Control & $33.9^{\mathrm{ns}}$ & $290.5 \mathrm{~A}$ & $579.2 \mathrm{~A}$ \\
\hline CD225 RR & 42.4 & $158.1 \mathrm{AB}$ & $269.1 \mathrm{~B}$ \\
\hline BRS 232 & 49.1 & $181.2 \mathrm{AB}$ & $189.2 \mathrm{~B}$ \\
\hline CD226 RR & 31.6 & $117.1 \mathrm{~B}$ & $148.0 \mathrm{~B}$ \\
\hline NK 7054 RR & 41.7 & $179.6 \mathrm{AB}$ & $247.4 \mathrm{~B}$ \\
\hline BMX Apollo RR & 43.7 & $181.9 \mathrm{AB}$ & $272.7 \mathrm{~B}$ \\
\hline BRS 245 RR & 44.0 & $128.5 \mathrm{~B}$ & $197.3 \mathrm{~B}$ \\
\hline BRS 255 RR & 40.4 & $216.1 \mathrm{AB}$ & $201.9 \mathrm{~B}$ \\
\hline Mean & 40.9 & 181.6 & 263.1 \\
\hline CV (\%) & 25.6 & 25.7 & 33.9 \\
\hline
\end{tabular}

${ }^{1 /}$ Means followed by the same letters, lowercase in rows and uppercase in columns, do not differ amongst themselves $(\mathrm{P} \leq$ 0.05 ) by Tukey's test. ${ }^{\text {ns }}$ Not significant by F test $(\mathrm{P}>0.05)$. 
to the late, due to a greater tolerance to competition, however, this was not a reflection of the superior ability of suppressing weeds. The results of HDM at 65 DAE were not confirmed at the time of harvest, because no differences were found among soybean cultivars, only between them and untreated soybean (Table 7). The lack of results may be related to the higher coefficient of variation in this assessment.

It is concluded that the reduction of yield due to interference with horseweed varies among the cultivars used at work. The cultivar BRS 232 stands out for the high yield and the small yield loss with horseweed interference condition. BRS 232 stands out positively as the plant height and dry matter of leaves at 20 DAE and dry matter of stems+branches in all evaluations. These characteristics are probably related to their higher performance and their greater ability to withstand competition with horseweed. There has been a mismatch between tolerance to competition and suppressive capacity of developing horseweed by soybean cultivars.

\section{ACKNOWLEDGMENTS}

To CNPq, by the concessions of financial resources and productivity sholarships in research to the first and third autors and undergraduate research scholarship to the fourth author.

\section{LITERATURE CITED}

BALBINOT JR., A. A. et al. Competitividade de cultivares de arroz irrigado com cultivar simuladora de arroz-vermelho. Pesq. Agropec. Bras., v. 38, n. 1, p. 53-59, 2003.

BIANCHI, M. A.; FLECK, N. G.; FEDERIZZI, L. C. Características de plantas de soja que conferem habilidade competitiva com plantas daninhas, Bragantia, v. 65, n. 4, p. 623-632, 2006.

BIANCHI, M. A. et al. Papéis do arranjo de plantas e do cultivar de soja no resultado da interferência com plantas competidoras. Planta Daninha, v. 28, p. 979-991, 2010. (Número Especial)
BHERING, S. B.; SANTOS, H. G. Mapa de Solos do Estado do Paraná - Legenda atualizada. Rio de Janeiro: Embrapa Florestas/Embrapa Solos/IAPAR, 2008. v. 1. 74 p.

BUHLER, D. D. Challenges and opportunities for integred weed management, Weed Sci., v. 50, n. 3, p. 273-280, 2002

EMPRESA BRASILEIRA DE PESQUISA AGROPECUÁRIA - EMBRAPA. Tecnologias de produção de soja - Região Central do Brasil 2009 e 2010. Disponível em: <http://www.cnpso.embrapa.br/download/ Tecnol2009.pdf> Acessado em: 20 de abr. de 2009.

GOLDBERG, D. E.; LANDA. K. Competitive effect and response: hierarchies and correlated traits in the early stages of competition, J. Ecol., v. 79, n. 4, p. 1013-1030, 1991.

HEAP, I. International survey of herbicide-resistant weeds. Online. $<$ http://www. weedscience.org $>$. Acessado em fev. de 2012.

JANNINK, J. L. et al. Index selection for weed suppressive ability in soybean, Crop Sci., v. 40, n. 4, p. 1087-1094, 2000

LAMEGO, F. P. et al. Tolerância à interferência de plantas competidoras e habilidade de supressão por genótipos de soja - II. Resposta de variáveis de produtividade.

Planta Daninha, v. 22, n. 4, p. 491-498, 2004.

LEMERLE, D. et al. Genetic improvement and agronomy forenhanced wheat competitiveness with weeds. Austr. J. Agric. Res., v. 52, n. 5, p. 527-548, 2001.

MONTEZUMA, M. C. et al. Avaliação da suspeita de buva (C. bonariensis e C. canadensis) ao herbicida glyphosate em pomares de citros no estado de São Paulo, In: CONGRESSO BRASILEIRO DE CIÊNCIA DAS PLANTAS DANINHAS, 25., 2006, Brasília, Resumos... Londrina: Sociedade Brasileira da Ciência das Plantas Daninhas, 2006. p. 564

PLACE, G. T. et al. Identifying soybean traits of interest for weed competition. Crop Sci., v. 51, n. 6, p. 2642-2654, 2011

VARGAS, L. et al. Buva (Conyza bonariensis) resistente ao glyphosate na região sul do Brasil, Planta Daninha, v. 25, n. 3, p. 573-578, 2007.

VIDAL, R.; MEROTTO Jr., A. Interação negativa entre plantas: inicialismo, alelopatia e competição. Porto Alegre: Ribas Antonio Vidal, 2010.

VOLLMANN, J. et al. The effects of simulated weed pressure on early maturity soybeans. Europ. J. Agron., v. 32, p. $243-248,2010$. 